\title{
Effect of Internal Financial Policy on Shareholders' Wealth and Firm Value
}

\author{
MOHAMMAD FAROOQ \\ Lecturer, Government College of Commerce Mehmandagencey \\ farooqkhanmuhmand@gmail.com \\ DR. ALAM REHMAN \\ Assistant Professor, NUML, Peshawar Campus \\ amrehman@numl.edu.pk \\ ADIL KHAN \\ MS Scholar NUML, Peshawar Campus \\ MOHAMMAD BILAL \\ MS Scholar NUML, Peshawar Campus
}

\begin{abstract}
This studyexamines the impact of internal financial policy on share holders' wealth and firm value. The study uses the data of manufacturing sector firms listed on PSE. The study apply random sampling techniques for the collection of data and total 91 firms selected as sample from different sub sectors in manufacturing sector. Stock price each share and firm value per share were taken as dependent variables whereas retained earnings per share and dividend paid per share used as independent variables and net total asset per share and firm value to book value per share taken as control variables. Panel data of all these variables used to examine the relationship of internal financial policy on stock price and firm value. The findings of this study indicate that dividen payout, retained earnings, and net total assets per share have positive and significant impact on stock price where as firm book value per share ratio has insignificant impact on stock price. Dividend payout shown strong relation with stock price as compare to retained earning. Dividend payout, retained earnings, net total assets per share have positive and significance relation with firm value and firm book value per share ratio has positive butinsignificant relationship with firm value. The study has some policy implications for the users and top management of these firms.
\end{abstract}

Keywords: $\quad$ Dividend payout, Retained earnings, Net total assets per share and Firm value to book value per share.

\section{Introduction}

Generally, in corporate sectors a finance manager addresses with some basic decisions. Those are Financing decision and Dividend decisions. Financing decisions indicate how the assets of a company should be financed for generating profit for organizations. When a firm starts producing revenue, then dividend policy decision originates in which a finance manager has two options. one is retained earnings and the other is dividend payout. Retained earnings policy is the other side or is sub policy of corporate main policy i.e., Dividend Policy. The retained earnings policy isanessentialand central policy; other corporate financial policies are formed under the light and objectives of dividend policy. (Ross et al.,2005) has examined components of earnings and 
determines how much amount should be retained and how much should be distributed among the shareholders or stakeholders of the company. The amount which is retained may be used for reinvestment, growth of the firm, future contingency events and paying different types of debts and interest thereon.

Decisions regardingdivisionof earnings between payment of dividend to shareholders and reinvestment some part of the profit in the companyis an imperative dimension of the financial policy of the firm. It is to be noted that retained earnings carry no transactions and liquidationexpenses (Altman, 1993). Retained earnings are a major source of supply of internal finance for the firms. Investors usually desire to have capital gains instead of dividends becausetaxes on capital gain may be delayedwhile they are taxed at low tax rates.Unlikely, dividend taxes are paid at the time when they are received at higher tax rates as compared to tax on capital gain.(Droms,1990) pointed out that shareholdersare more advantageous from reinvestment of earnings over a long-runperiod because of present and future growth opportunities in the company. Reinvestment of profit in the company results inincreasing the market price of firms' securities(Harkavy, 1953).

Haryanvi, (1953) examined the associations between retained earnings and share prices. According to the findings of the study, for a specificperiod, there was a tendency for prices of sharestowarddistinguishdirectlywith the ratio of dividend payments. Thus, organizations which retained a large proportion of its earning so automatically the prices of their shares go high up as compared to those whose retained earnings are tiny amounts of the total earnings. Retained earnings are significant sources of internal financing (is the part of the net profit that is reinvested in the business or intended to be reinvested)particularly in an exploring firm. According to (Gilchrist et al., 1995) thequantity of internal financeprovides information about the prediction ofgrowth of the firms. Growing firms typically pay minor dividends to shareholders because they reinvest this money or earnings in the operations of the firm and eventuallypay stakeholders a biggerratio of total returns as capital gains. Companies with few potential investment opportunities pay out a major part of net earnings to the stockholders.

Retained earnings are the amount which is not distributed among the shareholders or stakeholders, but it is retained for some emergency incidents. It is such an amount which is left for use in the company and for overcoming different needs and sudden incidents. Therate of retained earnings is based on the net income or the net loss if the net income is increased so with proportion to that the amount of retained earnings will be increased and it will be decreased with the proportion of net loss according to the will of the Board of Directors of the company. Dividend policy of the firms as well asthe role it plays in shaping the company'smarket value is an imperative topic that called for the attraction of researchers. A class of scholars on the topic has the viewthatdividend policy increases the stockholders wealth due to its effect on stock prices (Salih, 2010; Gordon, 1963). Another class has stated that dividend payments result in reducing shareholders wealth because ofdropping stock prices, and thereforedeclining value of the firm(Pettit, 1972).

Khan et al., (2013) has established that distinction in capitalstructure and retained earnings of the firms do have an effect on the stock prices of Pakistani manufacturing industry. Research work done in the past in most countries and in Pakistan, especially on the topic under study has mainly focused on the dividend payouts of corporate dividend policy and/ or external financial policy. Research, on the other side of Corporate Dividend Policy i.e., retained earnings have got very little importance. The distinctive feature of the study is that retained earnings ratio as a proxy for internal finance used 
as the main dependent variable; nonetheless dividend payout also given full emphasis. Thus, research study highlighted the effect of retained earnings with shareholder's wealth and firm's value and also the effect of dividend payout with shareholder's wealth and firm's value. This study is conducted with the aim to achieve the following objectives.s

1. To identify the effect of retained earnings (internal finance) with the shareholders' wealth and value of the firm per share.

2. To identify the effect of dividend payout with the shareholders' wealth and value of the firm per share.

\section{Litreture Reveiw}

Sharif et al., (2015) organized study on the topic of factors affect the stock price in Bahrain stock market. The authors result showed that variables like return on equity, book value per share, dividend per share, dividend yield, pricing earnings and firm size have significance relation with stock price. The researchers concluded that dividend payout is important factor among the observed variables which could influence the stock price and dividend payout should be ascertain in the determinants of stock price on Bahrain market. These results support the findings of (Masum, 2014) that dividend payout has affirmative and significance relation with stock price.

Osegbu et al., (2014) documented the association between distributed earnings and company performance. Researched was organized on banking industry in Nigeria and data collected from the period 1990 to 2010. Regression model was used for data analysis. The findings of the study indicated that there is insignificance association between distributed earning and firm performance. According to the authors those other four independent variables ( free cash flow, financial leverage, business risk and tax paid on distributed earnings ratio ) have also found no significance relationship with dividend policy.

Omete, (2013) scrutinized the impact of following factors i.e. earnings per share, distributed earnings each share and price to earnings ratio which could influence the changes in the shareholders' wealth of the company. The researched conducted in Kenya and at the beginning of the stock market period the results showed that income each stock, dividend each share and price to earnings ratio have direct and significance association with shareholders' wealth.

Mohammad et al.,(2012) scrutinize the empirical relationship of dividend policy with share holders' wealth in the Malaysian market. Results of the study show that there is inverse association between stock price and dividend policy. Dividend policy was measured with two components which were dividend yield and distributed earnings. The authors concluded that share price mostly influenced by size and dividend yield.

Fargher and Weigand.,(2009) studied the launching of distributed earnings and factors related that influence launching and constant distribution of dividends to the stockholders. The researchers found that companies usually initiate distribution of their earnings when firms have less investment opportunities to further spread their businesses. The study conducted on sample of 594 companies from 1964 to 2000 and those companies which had launched distribution of earnings. The researchers observed improved profit when the firms did not paying dividend but investigated lower profit when the firms starts the distribution of earnings. The authors concluded that retained benefit those firms which have investment opportunities and if there is less investment opportunities firms starts paying of dividends.

$\mathrm{Li}$ and Zhao.,(2008) conducted a research to investigate the relationship of informational asymmetries on the internal financial policies of the firms. The researchers 
adopted and verify the entailments of the dividend signaling model. They also determine the distributed earnings and shares buy back operations in successful informational atmosphere. For testing the data the authors used dividend policy model to test it empirically. The results indicated that mature and profitable firms with less investment opportunities distribute more of their earnings to their shareholders. Asymmetries information has inversely associated with internal financial policies. Organizations keep more of their retained earnings having potential investment opportunities.

Pandey and Bhat.,(2007) studied earnings policy of selected companies with in organized environment of Indian monetary policy. The researchers collected data from 571 non financial companies annually data from 1989 to 1997 were used for the study. The researchers indicated that planned paid earnings portions were less and shown that dividend behavior were not constant so the researchers concluded that when there is an investment opportunity Indian firm first priority is retained earnings to use it for investments.

Mizuno, (2007) studied Japanese corporate manager's perception regard their organizations' payout decisions. The researcher arranged a survey research picking data from 310 Japanese listed organizations. The researcher investigated that maximum numbers of Japanese firms' belief that dividend as the main resource of distributed earned capital to stock holders. The selected firms also give importance to fixed payout of dividend. Almost one third of the selected firms had kept a specific mark of dividend payout. The remaining firms' beliefs that investment opportunities would be avail before paying dividend. In the situation between debt payments and dividend payout the selected firms' managers thinks that debts payment is a primary and important decision for them. More than fifty percent of opinions indicated that growth in dividend show increase in the value of firms. eight out of ten respondents thinks that dividend policy strongly related with firm value.

Feng, et al.,(2007) scrutinized the association of CEO in direct selection of dividend payout policies. The research was conducted on Real Estate Investment Trust firms listed in USA. For analysis 236 firms were selected for the study and data taken from 1999 to 2000. Optimal entrenchment proposition were addressed in the study. Basic purpose of the study was to monitor the activities of shareholders with their agents. Due direct selection of CEO in choosing the portion of dividend payout in last half decade $144 \%$ of their net incomes were distributed among shareholders. The researchers empirically test the data and found those CEOs who were high entrenched had distributed $60 \%$ more of their net earnings as compare to the low entrenched CEOs. The researchers concluded that involvement of CEOs in direct selection have negatively effects the value of the selected firms because they focused the interest of shareholders only.

Booth and Cleary.,(2006) organized study in Canada to estimate firm's growth opportunities in the environment of limited financing. The researchers found that financial limitations were considered as a block amid the acquisition of internal and external funds for the firms. The researchers identify that getting external funds for investments opportunities are more expensive as compare to internal funds. The researchers worked on the model of (Miller and Modigilani., 1961) named "Investment Opportunities Formula". The researchers customized this model according to their own study and empirically tested the observed data. The researchers collect data from 1981 to 1998 and the sample size was 1133 US firms with yearly observations of 20394. The results of the model showed that there is direct and significance relationship amid internal finance with firm growth opportunities. The researchers accomplished that the US firms 
keep suitable amount of cash due to unpredictability cash flow in the future and the observed firms can used these funds in investments projects.

De-Angelo and Stulz.,(2004) explained the collection of retained earnings and related factors which enforce a firm to stop distribution of dividend to shareholders. For analysis 25 largest-standing firms were selected as sample of the study and data were collected from 1973 to 2002. These firms had retained earnings with worth of 1.8 trillion US dollars which was more than $50 \%$ of total assets of these firms. The purpose of the research was to investigate the relationship of dividend payout with high level of equity. The researchers investigated that dividend payout had positive relationship with size and profitability level. The researchers also summaries that capital and assets structure gives clear information about dividend policy that how much should be distributed and how much should be retained and level of equity can bring changes in dividend policy.

Brien,(2003) conducted a study to find the relationship of industrial innovative competitive strategy of the firms on its capital structure. The researcher observed Research and Development as the main factor for lower leverage. The author linked plow back earnings with lower level of corporate leverage because retained earnings are the best source to use in unforeseen events and investments opportunities. The sample size of the research was 16,358 registered companies and yearly data from 1980 to 1990 was collected for the study. The researcher indicated from the given data the firm planned directions are strongly linked with best survival position in the market. Retained earnings and Research and Development are main factors for obtaining competitive position in the market.

Brav, et al.,(2003) explained the distributed earnings strategies of USA and Canadian firms by organizing surveys of 384 Chief Financial Officers and Treasures. The researchers investigated main influencing factors for distributed earning as well as stock buyback strategies. The size of the sample was 384 Financials executives and a survey questionnaire was used for collecting data. The researchers also organized unstructured closed interviews with Chief Financial Officers and Treasurer of 23 sample public firms. The authors selected firms which were large in size and also with high volume of sale. CEOs were empowered in relating dividend strategies. The researchers found that managers increase the amount retained earnings under extreme conditions and when firms did not adopting the strategies of stock buyback then distributed their earnings to share holders. The researchers noticed some contribution elements like earnings each stock, liquidity cost, flotation cost, credit rating, capital structure which set the direction for distributed earnings strategies.

Opler et al., (2001) studied the scope of retained earnings and marketable securities. A sample consist of 24 industrial registered companies and an annually data from 1952 to 1994 collected. The researcher investigated some results that, normally, observed companies kept under ten percent of liquids to net assts. The researcher also found that immature companies kept sufficient amount of cash and their market value is lower to book value. Some factors like those companies where their managers hold ownership more than five percent, it influence the level of retained earnings and managers looking for suitable investment opportunities. The researchers indicated that retained earnings are firm main source to respond to unforeseen events.

Groves and Samuels(1976) discuss the basis notion of retained earnings relationship with the notion of costs and deferred taxes. The researchers supposed two companies like ' $\mathrm{X}$ ' and ' $\mathrm{Y}$ ' with parallel formation and financial resources. The selected 
two companies adopted dissimilar behavior concerning its earnings. The first company distributed all their earnings and the second company kept all its earnings. The results indicated that the first company which distributed all its earnings has maximize the value of their shareholders but the second company which kept all its earnings has decrease the value of shareholders. Thus the researchers summarize that dividend payout increase the value of shareholders whereas retained earnings did not maximize.

Bates and Henderson(1967) identify that one of the most important source of finance for small enterprises is an internal finance which is a low cost source of fund raising. However, large firms and public companies having the capacity to incur the cost of raising finance from the external sources of funding, while small firms lacking this opportunity due to its size and ability to observe the pressure of debtors. The small firm can grow if it retains major portion of its profit as retained earnings.

\subsection{Theoretical Framework}

After the review of relevant literarure, the following theoretical framework has been developed.

- Retained Earnings of the firm

- Dividend payout by the firm

- Net Total Assets per Share

- Market Price-to-Book Value Ratio

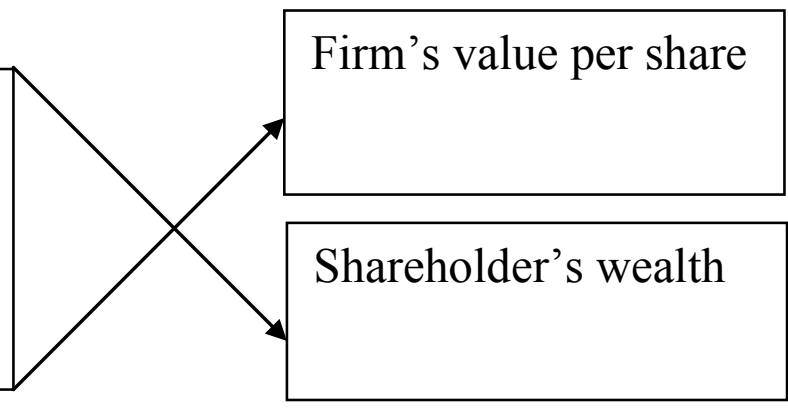

\subsection{Research Hypotheses}

The research is based on the following hypothesis

$\boldsymbol{H}_{1:} \quad$ Retained earnings have significance relationship with firm's value per share (performance).

$\boldsymbol{H}_{2:} \quad$ Retained earnings hav significance relationship with stock price (Shareholders' wealth).

$\boldsymbol{H}_{3:} \quad$ Dividend payout has significance relationship with firm's value per share (performance).

$\boldsymbol{H}_{4:} \quad$ Dividend payout has significance relationship with stock price (Shareholders' wealth).

$\boldsymbol{H}_{5:} \quad$ Net total assetes have significance relationship with firm's value per share (performance).

$\boldsymbol{H}_{6:} \quad$ Net total assets have significance relationship with stock price (Shareholders' wealth).

$\boldsymbol{H}_{7:} \quad$ Market price to book ratio has significance relationship with firm's value per share (performance).

$\boldsymbol{H}_{8:} \quad$ Market price to book ratio has significance relationship with stock price (Shareholders' wealth).

\subsection{Operational Definitions and Measurment}

The study uses independent and dependent variables to set the hypothesis of this study. All thesevariables have been operationally defined and measured below.

\subsection{Dependent Variables}

Following dependent variables have been used in this study.

\subsubsection{Firm Value per share}


Firm value is the first dependent variable in the models of the study and it is defined by (Gentry et al.,2003).

$$
\text { Firm Value per share }=\frac{\text { Total net asset }+ \text { Total long Term liabilities }}{\text { No of share outstanding }}
$$

\subsubsection{Shareholders' Wealth}

Shareholders' Wealth used as second explained variable in the models of the study and defined by (Botha, et al., 1987).

Share Holder's Wealth $=$ No of Common shares Outstanding $\times$ Market Value per Share

\subsection{Independent Variables}

Following independent variables have been usesd in this study.

\subsubsection{Retained Earnings (Retention Policy)}

Retained Earnings is the independent variable in the model and it is defined by (Copeland et al,. 2007).

\subsubsection{Dividend Payout (Dividend Policy of the Firm)}

$$
\text { Retained earnings per share }=\frac{\text { Net Income After tax }- \text { Dividend Paid }}{\text { No. Of Shares Outstanding }}
$$

Dividends are called shareholders' wages (Graham and Dodd., 1951) portion of earnings that is paid to shareholders (Mahapatra and Mahapatra.,2004).

This is represented mathematically as follows.

$$
\text { Dividend Paid Ratio }=\frac{\text { Dividend Paid }}{\text { Net Income After tax }} * 100 \%
$$

\subsubsection{Market Price-to-Book Value Ratio}

The Price to Book ratio compare the firm's market value to the book value of that firm'sas reported in its financial statements(Murray \& Block., 1989).

$$
\text { Market Price-to-Book Value Ratio }=\frac{\text { MarketShare Price }}{\text { Book Value PerShare }}
$$

\subsubsection{Net Total Assets per Share}

Assets refer to properties owned by a company and have value and can be converted intocash or can be used to generate cash or used to meet debts and the related commitments(Sullivan \& Steven., 2003).

$$
\text { Net Total Assets per Share }=\frac{\text { Net Total Assets }}{\text { No.of Shares Outstanding }}
$$

\subsection{Research Models}

The following model has been used to test the hypothesis of the study.

$$
\begin{aligned}
& \text { LnSPPS }_{i t}=\beta 0+\beta 1 \text { RPS }_{i t}+\beta 2 \text { DPS }_{i t}+\beta 3 \text { NTAPS }_{i t}+\beta 4 \text { FVBVPS }_{i t}+ \\
& \text { E.......... Equation(i) } \\
& \text { LnFVPS }_{i t}=\beta 0+\beta 1 \text { RPS }_{i t}+\beta 2 \text { DPS }_{i t}+\beta 3 \text { NTAPS }_{i t}+\beta 4 \text { FVBVS }_{i t}+
\end{aligned}
$$

\section{Research Methodology}

This is a quantitative research as the secondary data has been quantitatively quantified. The relationship between independent variables and denpendent variable have been analyzed and investigated through correlation and regression analysis. This research aimed to analyze the effect of internal financial policy with shareholder s' wealth and firm's value per share of manufacturing sector companies of Pakistan. There are 438 manufacturing firms available on Pakistan Stock Exchange. The manufacturing sector was selected for the population of this study. . In selecting sampling data, six years consecutive financial data of the company available on data sources used. A sample 
containing ninety one firms out of (438 firms available on PSX) from the manufacturing sector of Pakistan, which are listed on Pakistan Stock Exchange for the period with effect from the year 2009 to 2014 has selected for analyzing the impact retained earnings and dividend payouts on the firm's value and stock prices.

\section{Results and Discussion \\ 4.1 Hausman Test}

The hausman test conducted to find the appropriate model for the data. The results demonstrate that the probability value of the test is above than $5 \%$ which suggest that random effect model is an appropriate model for testing the data.

\subsection{Random Effect Model of Stock Price}

Table 4.1 Random Effect Model of Stock Price

\begin{tabular}{lcccc}
\hline \hline Variables & Coefficient & Std. Error & T-ratio & P-value \\
\hline \hline Const & 3.5014 & 0.0627 & 55.7954 & 0.0001 \\
RPS & 0.0017 & 0.0006 & 2.7278 & 0.0066 \\
DPS & 0.0175 & 0.0039 & 4.4435 & 0.0001 \\
NTAPS & 0.0001 & 0.0001 & 2.8823 & 0.0041 \\
FVBVPS & 0.0122 & 0.0326 & 0.3753 & 0.7076
\end{tabular}

\section{R-squared 0.8614}

F-value 36.9696

P-value $<0.0001$

The current study reveals the outcomes of regression test of internal financial policy with share holder's holder wealth. The test was applied to analyze the impact of internal financial policy on share holder's wealth. The $\mathrm{R}^{2}$ value is 0.8614 which shows that the impact of retained earnings, dividend payout, net total asset per share and firm value to book value per share on share holder's wealth is 86 percent. Means that around $86 \%$ of the changeability in the ending price of the stock can be detailed by the association among cash dividends for each share, earnings per share, net total assets per share and firm value to book value per share) as explanatory variables and the ending price of the stock, whereas $14 \%$ of the changeability in the ending price of the stock effect by outside factors. Model is found statistically significant F- value is 36.9696 and $\mathrm{P}$ - value is $<0.0001$ which is a smaller than $5 \%$.

The coefficient value of retained earnings equals .0017 where the symbol is positive indicating retained earnings have affirmative relationship with share holder's wealth. It concludes that if the retained earnings of the firm goes in growing the value of shareholders will also be enhanced. The slope of the coefficients suggests that a 1 percent increase in retained earnings per share there will be 0.17 percent increase in the price of a stock. Retained earnings has p-value of 0.0066 which is fewer than $5 \%$.

The coefficient value of dividend payout equals 0.0175 where the symbol is positive indicating dividend payout possesses affirmative association with share holder's wealth. It concludes that if the payment of dividend moves upward, the value of shareholders will also be rising eventually. The slope of the coefficients suggests that a $1 \%$ rise in dividend payout for each share may increase 1.75 percent the value of stock price for each share.Dividend payout has p-value of 0.0001 which is less than $5 \%$.

The coefficient value of the net total assets per share is 0.0001 ; the positive symbol of coefficient indicates that the net total assets per share have affirmative association with share holder's wealth. It means that if the net total assets per share of the firm moves in raising the value of shareholders will also be raise. The slope of the 
coefficients suggested that a 1 unit in total assets per share has an increase of 0.01 percent in the value of stock price.Net total assets has p-value of 0.0041 which is less than $5 \%$.

The coefficient value of firm value is -0.0122 whether the negative coefficient shows that the firm value to book value per share has negative relationship with share holder's wealth. It means that if the firm value to book value per share of the firm goes in increasing the value of shareholders will be decrease. The slopes of the coefficients suggested that 1 percent increase in firm value to book value ratio for each share have a decrease of 1.22 percent in price of stock. The p-value of the firm value to book value per share is 0.7076 , which is more than 0.05 it shows insignificance relation with dependent variable.

4.3 Random Effect Model of Firm Value

Table 4.2 Random Effect Model of Firm Value

\begin{tabular}{|c|c|c|c|c|c|}
\hline Variables & Coefficien & & Std. Error & T-ratio & P-value \\
\hline Const & 4.0645 & & 0.0461 & 87.9887 & 0.0001 \\
\hline RPS & 0.0010 & & 0.0004 & 2.3076 & 0.0214 \\
\hline DPS & 0.0108 & & 0.0028 & 3.7829 & 0.0001 \\
\hline NTAPS & 0.0001 & 0.0001 & 5.6057 & & 0.0001 \\
\hline FVBVPS & 0.0169 & & 0.0237 & 0.7121 & 0.4767 \\
\hline
\end{tabular}

\section{R-squared 0.8570}

F-value 35.4860

P-value $<\mathbf{0 . 0 0 0 1}$

The table given reveals the regression test output of internal financial policy on Firm's value for each share.Thetest was applied to confirm the impact of internal financial policy on firm's value for each share. The $\mathrm{R}^{2}$ value is equal to 0.8570 showing the impact of retained earnings, dividend payout, net total asset per share and firm value to book value per share on share holder's wealth is 85 percent. Means that approximately $85 \%$ of the variability in the firm value per share can be explained by the relationship between (dividends for each share and earnings for each share, net total assets per share and firm value to book value per share) as independent variables and the firm value per share, while $15 \%$ of the variability in the firm value per share caused by external factors. Model is found statistically significant F-value is 35.4860 and The p-value of the model is $<0.0001$ and it is less than $5 \%$.

The value of coefficient of the retained earnings is 0.0010; sign of coefficient means retained earnings have optimisticassociation with share holder's wealth. It means that if the retained earnings of the firm goes in increasing the value of shareholders will also be increase. The slope of the coefficients suggests that a 1 percent increase in retained earnings per share there will be 0.1 percent increase in the firm value per share. Retained earnings have p-valueof0.0214and it is less than 5\%.

The value of coefficient of the dividend payout is 0.0108 ; sign of coefficient means dividend payout has positive relationship with share holder's wealth. if the dividend payout of the firm goes in increasing the value of shareholders will also be increase. The slope of the coefficients suggests that a 1 percent increase in dividend payout per share there will be 1.08 percent increase in the firm value per share.Dividend payout has p-value of 0.0001 and it is less than $5 \%$.

The value of coefficient of the net total assets per share is 0.0001 , the positive sign of coefficients shows that the net total assets per share have positive relationship with share holder's wealth. It means that if the net total assets per share of the firm goes in increasing the value of shareholders will also be increase. The slope of the coefficients 
suggests that a 1 percent increase in net total assets per share there will be 0.01 percent increase in the firm value per share.Net total assets has p-value of $<0.0001$ and it is less than $5 \%$.

The value of coefficient of the firm value to book value per share is 0.0169 , the positive sign of coefficient shows that the firm value to book value per share has positive relationship with share holder's wealth. It means that if the firm value to book value per share of the firm goes in increasing the value of shareholders will also be increase. The slope of the coefficients suggest that a 1 percent increase in firm value to book value per share there will be 1.69percent increase in the firm value per share. The p-value of the firm value to book value per share is 0.4767 , which is more than 0.05 .

\section{Conclusion}

The present study has beenconducted on the manufacturing sector companies in Pakistan. Manufacturing companies which were listed at Pakistan Stock Exchange have been selected for population of the study. The size of the sample comprise of 91 firms which select on the baise of simple RandomSampling technique that listed on pakistan stock exchange.Stock price each share and firm value per share were taken as dependent variables whereas retained earnings per share and dividend paid per share used as independent variables and net total asset per share and firm value to book value per share taken as control variables. Panel data of all these variables used to examine the relationship of internal financial policy on stock price and firm value. The findings of this study indicate that dividen payout, retained earnings, and net total assets per share have positive and significant impact on stock price where as firm book value per share ratio has insignificant impact on stock price. Dividend payout shown strong relation with stock price as compare to retained earning. Dividend payout, retained earnings, net total assets per share have positive and significance relation with firm value and firm book value per share ratio has positive but insignificant relationship with firm value. The study has some policy implications for the users and top management of these firms. The same kind of studies can also be tested for the comparison of manufacturing and financial sectors.

\section{References}

Al-Malkawi, H. N. (2008). Factors Influencing Corporate Dividend Decision: Evidence from Jordanian Panel Data. International Journal of Business, 13 (2), pp. 177195.

Amidu, M. (2007). How Does Dividend Policy Affect Performance of the Firm on Ghanatock Exchange, Investment Management and Financial Innovations, Volume 4(2).

Baker, H.,G. Farrelly \& Edelman, R. (1985). A survey of management views on dividend policy. Financial Management, Vol. 14(3), pp. 78-84.

Baum, A. \& Neil, T. (2004). Retention rates, Reinvestment and Depreciation in European Office Markets. Journal of Property Investment \& Finance, 22(3), 214235.Retrieved June 07, 2010, from http://www. emeraldinsight.com/1463578X.htmBenson, Bradley.

Booth, L. \& Sean, C. (2006). Cash Flow Volatility, Financial Slack andInvestment Decisions, A Research Project. Google Search Engine (online). RetrievedDecember 29, 2009, from http://www/google.com

Brav, A., Graham, J., Harvey, R., Campbell, R. \& Michaely, R. (2003). Payout Policy in the 21st Century. Google Scholar Research Database (online). RetrievedFebruary 15, 2009, from http://scholar.google.com.pk 
Copeland,E., Weston, T., Fred, J. \& Kuldeep, S. (2007). Financial Theory and Corporate Policy (4th ed.). In Dividend Policy: Theory and Empirical Evidence (chap. 16).India: Dorling Kindersley Publishing Inc.

Dasilas,I., Katerinaand, A. L., \& Ginoglou, D. (2009). the impact of dividend initiations on Greek listed firms' wealth and volatility across information environments. Managerial Finance, 35(6), 531-543. Retrieved February22, 2010, from http://www.emeraldinsight.com/0307-4358.htm

De-Angelo, Harry, DeAngelo, Linda., \& Stulz, Rene, M. (2004). Dividend Policy, Agency Costs and Earned Equity. Social Science Research Network Electronic Publishing Inc. Retrieved March 20, 2009, from http://www.ssrn.com/abstract $=558747$

Elston, J. A. (1996). Dividend Policy and Investment: Theory and Evidence from US Panel Data. Managerial and Decision Economics, 17, 267-275. Retrieved January 29,2010, fromhttp://www3.interscience.wiley.com/cgi/bin/fulltext/

Fama, E., French, F. \& Kenneth, R. (1998). Taxes, Financing Decisions, and FirmValue.The Journal of Finance, LIII(3), 819-843. Retrieved January 29, 2010,http://www3.interscience.wiley.com/cgi/bin/fulltext/

Fargher, N. L. and W.A. Robert. 2009. Cross-sectional Differences in the Profits,Returns and Risk of Firms Initiating Dividends. Managerial Finance, 35(6), 509-530. Retrieved January 10, 2010, from http://www.emeraldinsight.com/03074358.htm

Farrelly, G., Bakerand, H . \&. Edelman, R. (1986). Corporate dividends: Views of the policy makers, Akron Business and Economic Review, Vol. 17, No. 4, 62-74.

Ghosh, C., \& Woolridge, J. R. (1989). Stock-Market Reaction to Growth-induced DividendCuts: Are Investors Myopic? Managerial and Decision Economics, 10, 22-35. Retrieved January 29, 2010, from http:// www3.interscience. wiley. com/cgi/bin/fulltext/

Grinstein, Y. \& Michaely, R. (2005).Institutional Holdings and Payout Policy.The Journal of Finance, LX(3), 1389-1426. Retrieved January 29, 2010, fromhttp://www3.interscience.wiley.com/cgi/bin/fulltext/

Harkavy, O. (1953).the relation between retained earnings and common stock prices for large listed corporations, Journal of Finance, Vol. 8, Issue, 3, pp. 283-297.

Kaestner, R. \& F.LIU. (1998). New Evidence on the Information Content of Announcements.The Quarterly Review of Economics and Finance, 38. (2), pp. $251-274$

Li, K. \& Z.Xinlei. (2008). Asymmetric Information and Dividend Policy. FinancialManagement, winter edition, 673-694. Retrieved January 01, 2010, fromhttp://www.interscience.wiley.com

Mahapatra, R. P. \& Mahapatra, K. C. (2004). Corporate Dividend Policy (1st ed.). In Theory of DividendPolicy(chap. 01). New Delhi (India): Sonali Publications.

Mehar, A. (2007). Corporate Governance and Dividend Policy.Munich Personal RePEcArchive, 1-13. Retrieved March 12, 2009, from http://mpra.ub.unimuenchen.de/619/

Miller, M. \& Rock, K. (1985). Dividend Policy under Asymmetric Information. Journal of Finance, September, 1031-1051.

Mohammad, H., Ardekani, A. M. \& Younesi, N. (2012). The Impact of Dividend Policy on Share Price Volatility in the Malaysian Stock Market. Journal of BusinessStudies Quarterly, 4(1), 111-29. 
Naamon, H. (1989). Dividend policy and its impact on the stock price in the industrial public shareholding companies listed on the Amman Financial Market, MA thesis, the University of Jordan, Amman, Jordan.

Nishat, M. (1992). Share Prices, Dividend and Retained Earnings Behavior in Pakistan Stock Market. Indian Economic Journal, Vol. 40(2), pp. 57-56.

Omete, F. I. (2013). The Effects Of Earnings Per Share, Dividend Per Share And PriceTo Earnings Ratio On Share Prices: The Case of Firms Listed At NairobiSecurities Exchange. Innovational Study of Innovative Research and Studies, 2(9),30-44.

Osegbue, I.F., Ifurueze, M. \& Ifurueze, P. (2014). An analysis of the relationship between dividend payment and corporate performance of Nigerian banks. Global Business and Economic Research Journal, 3(2), 75-95.

Panday, I. M. \& Ramesh, B. (2007). Dividend Behaviour of Indian Companies Under Monetary Policy Restrictions. Managerial Finance, 33(1), 14-25.

Power, D. \& MacDonald, R. (1995). Stock prices, dividends and retention: Long-run relationships and short-run dynamics. Journal of Empirical Finance, Vol. 2(2), pp. 135-151.

Pradhan, R. (2003). Effects of dividends on common stock prices: The Nepalese evidence, Available at SSRN: http://ssrn.com/abstract=1403725.

Salih, A.A. (2010). The effect of dividend policy on market value: UK empirical study, Doctoral thesis, Durham University. Available at Durham e-theses online: http:// etheses.dur.ac.uk/556/.

Sembenelli, A. (1993). Signalling, Financial Hierarchy and Agency Theory asExplanations for Dividend Behaviour: Evidence from Italian Firm Data. Managerial and Decision Economics, 14, 37-45. Retrieved January 29, 2010,http://www3.interscience.wiley.com/cgi/bin/fulltext/

Sethi,S. \& Taksar, I. M. (2002). Optimal Financing of a Corporation Subjectto Random Returns. Mathematical Finance, 12(2), 155-172. Retrieved January 6,2009, from http://www.interscience.wiley.com

Sharif, T., Purohitand, H.\& Pillai, R. (2015). Analysis of Factors Affecting Share Prices: The Case of Bahrain StockExchange. International Journal of Economics and Finance; Vol. 7(3).

Troudi, W. A. (2013). Cash Dividends, Retained Earnings and Stock Prices: Evidence from Jordan. Interdisciplinary Journal of Contemporary Research in Business, Vol .4(12) copy right (C) 2013 Institute of Interdisciplinary Business Research 585 April 